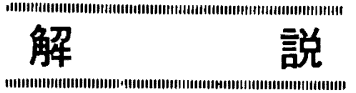

UDC $536.5 .088: 536.5 .081$

\title{
測温の 精度と標準についで
}

（国際温度標準の変更にあたつて）

\author{
高 田 誠 二**
}

\section{Accuracy and Standards of Temperature Measurement}

\author{
Seiji TAKata
}

\section{1. 序説一温度計測標準のトレーサビリティ* とその意義}

鉄鋼業は温度計測研究の母体であるとも言えよう、筆 者のもつ断片的な知識の中でさえ, 19世紀後半のドイッ における鉄鋼業の躍進と熱電的あるいは光学的な温度計 測技法の実用化との関連とか, 昭和 10 年代以後に日本 学術振興会の分科会を中心として根気よく続けられてき ている製鉄製鋼のための温度計測研究1)2) とかの話題は, 強い印象のもとに記憶されている. 近時の鉄鋼プロセス で利用されている温度計測技法3), 温度制御の手法4), 計 算機制御の実例)は，“かん”だけをたよりにしていたと 言われるかつての鉄鋼操業のイメージをほとんど全面的 にチェンジしてしまつたに違いない，有名な温度シンポ ジウムの第 5 回 (5th Symposium on Temperature, its Measurement and Control in Science and Industry, 米国ワシントン, 1971年 7 月) に際して, 赤外線 ITV による温度パターン計測技法とその高炉炉頂部装入物の 温度パターン計測への応用という,すぐれた成果が日本 から発表された6)ことは，この分野でのわが国の技術レ ベルの高さを物語つていると言えるであろう.

計測技術の進歩にはいろいろな段階がありうるが，そ の第一歩は“測れなかつたものを測れるようにする”こ とをおいて他にありえまい，操炉に際して熟練者が肉眼 で炉況を判定する以外に力法がなかつた時期と比べれば ともかくも熱電温度計をそう入するなり光高温計で観望 するなりして“測れる”ようになつたということ自体が 画期的な進歩であつて，その測定の精度（正確さ and/ or 精密さ）の吟味などは，その次の段階の問題に属す る. 一方赤外線 ITV による高炉内温度パターン計測の ような例では，測れなかつたものをはじめて測つたとい

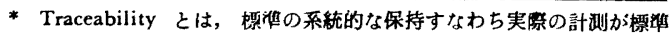
と正しく関原つけられていろかどうかという意味
う意義に加えて, ある空間領域内の温度分布の特徵的パ ターンを一挙にとらえるという新しい意義が顕著に認め られる，この例でも，“真”温度は?，実勃放射率は? と いつた吟味は二の次と考えていつこうに差しつかえはな w.

しかしながら，まさにその“次”の段階においては， 温度計測の精度は? 真温度は? という問いが重大な意味 を露呈することになるはずである.今日“あるひとつの” 熱電温度計をたよりにして操業をし，明日“他のひとつ の”熱電温度計に切り変えて操業をしょうという場合 に, 操業条件の再現性ひいては製品の品質や生産量の安 定度は一体どの程度まで保証されるのか。同じく赤外線 に着目するとしても，ITV を利用して得た結果 と赤外 2 波長温度計を利用して得た結果とでは，その解釈のう えに少なからぬ差異があるべきではないのか. “あるひ とつの”事業場に設置されている光電高温計と“他のひ とつの”事業場に設置されているそれとを仮に交換した として, 計測の結果に食い違いが生じないであろうか。 企業合併の際に両者の計測システムはすんなりと結合で きるものであろうか.

情報化，システム化のすう勢は鉄鋼業界においてもす でに顕著であろうが，情報の一般性を高めシステムの機 能の信頼性を高めるためにも，計測はますます重視され なければならない，一般性と信頼性を志向する意味での 計測は不可避的に普遍性を要請するはずである. 大量か つ高速に流通する情報によつて動かされる巨大なシステ ムが有機的な機能を発揮しうるためには，情報の源とな る測定値の一貫性が保証されていなければならない.

測定とは“基準量と比較して，数值を用い量を表わす 操作”であるとされている（JIS Z8104「計測用語（計 測一般)」). 測定値の一貫性の問題は主として“基準量

* 昭和 46 年 9 月 20 日受付 (依頼解説)

** 計量研究所工缆 


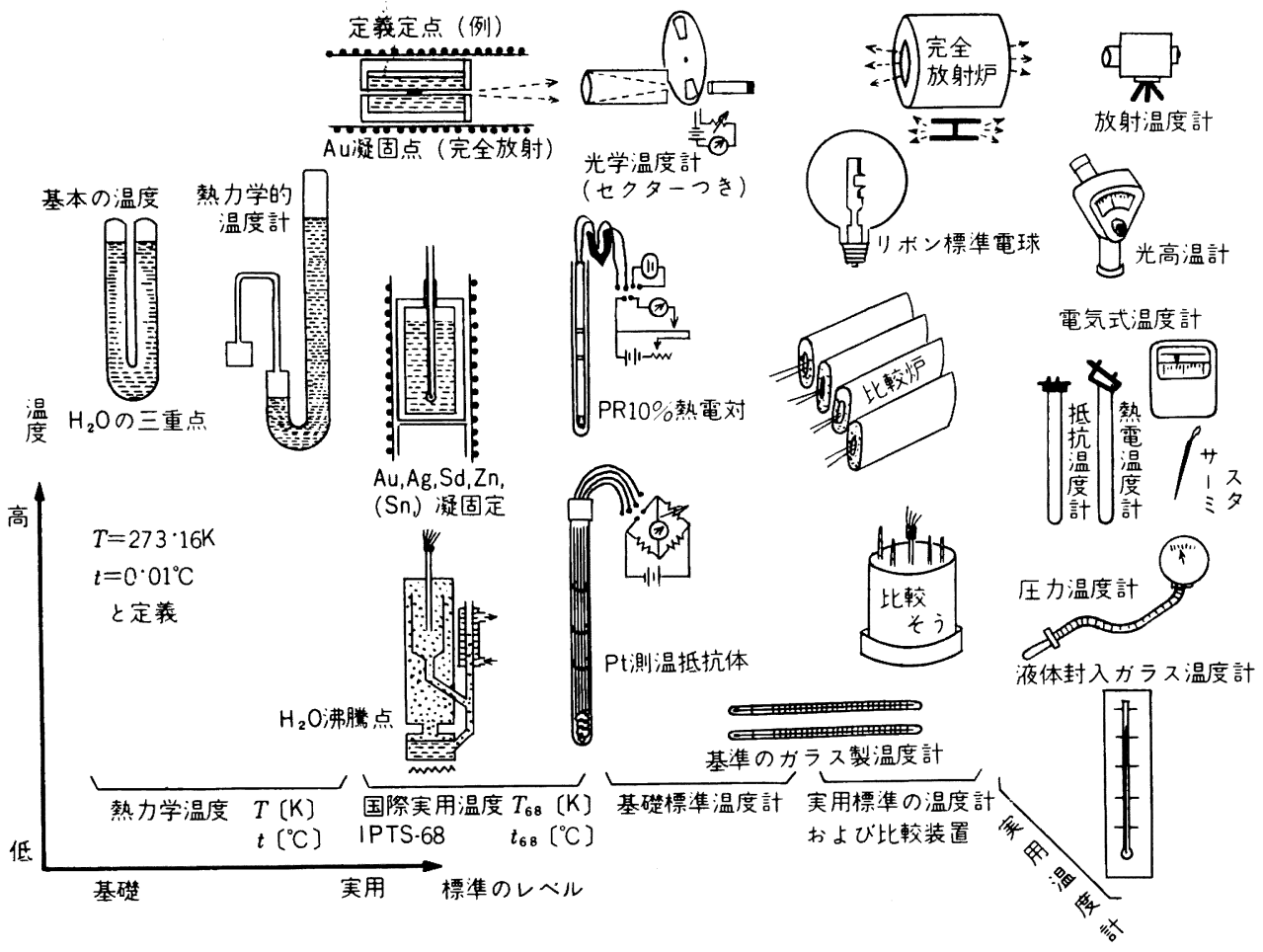

図 1 温度計测標準のトレーサビリティ（traceability）

との比較”の問題に帰着すると言えよう。これを温度計 測の場合について具体的に考えれば，さきにあけ゚たよう な各種の温度計が，それぞれさまざまな条件下で，一䁚 性ある測定值を示すかどうかの問題に通ずるのであり， さらに現実的に言えば，図1に示すような体系（この図 は，すでに多くの機会に利用したものの再録であつて， 恐縮であるが）の全体の一貫性が確保されていて“基準 量との比較” が，現場から基礎標準研究所に至るまで, 矛盾なく結びつけられているかどうか（いわゆる標準の トレーサビリティが整えられているかビうか）の問題に 通ずるわけである.

\section{2. 現場の温度計測標準}

図1の右端は現場すなわち温度計測の最前線を意味す る. 鉄鋼業の場合について言えば，温度計測の最前線と は, 浸漬熱電対または 2 色温度計による溶銑温度の測 定, P R 熱電対による熱風炉炉内温度の測定, 消耗形熱 電対による溶鋼温度の測定，放射温度計または光電管温 度計による圧延温度の測定などが，交字どおりの最前線 に相当することになろうが，社内の分析室や研究室では 液体封入ガラス温度計や測温抵抗体による精密な温度測 定が重要な役をはたしているであろう。こうして列挙 してみれば，鉄鋼業では，図 1 右端に示すような温度計
のほとんどすべてのタイプのものが，日常的に利用され ているわけである.

さて，それらの温度計の正確さはどのようにして確保 されるのであろうか. 基準との比較はどのようにして行 なわれるのであろうか. 幸いにして最近この種の問題に 関する代表的な例解の発表?)に接することができたので その要点を表 1 と表 2 に紹介しておく.

表 1 は鉄鋼プラントにおける温度計測の 2 次標準の例 であつて，これらは常用温度計のチェックのために用い られる.すなわちこれらの 2 次標準は図 1 右端から一歩 だけ左へ寄つた段階での基準の役をするのである．表 1

表 1 鉄鋼業における温度計測の 2 次標準の例?)

\begin{tabular}{|c|c|c|}
\hline 名 & 適用温度範囲 & $\begin{array}{l}\text { 比較の対象とす } \\
\text { る1 次標準 }\end{array}$ \\
\hline Pt 測温抵抗体 & $-200 \sim 1630^{\circ} \mathrm{C}$ & Pt 測温抵抗体 \\
\hline $\mathrm{PtRh} \cdot \mathrm{Pt}$ 熱電対 & $600 \sim 1700^{\circ} \mathrm{C}$ & $\begin{array}{l}\text { PtRh·Pt 熱電対, } \\
\text { Pd 線 }\end{array}$ \\
\hline CA 熱電対 & $400 \sim 1200^{\circ} \mathrm{C}$ & $\begin{array}{c}400 \sim 600^{\circ} \mathrm{C}: \\
\mathrm{Pt} \text { 測温抵抗体 } \\
600 \sim 1200^{\circ} \mathrm{C}: \\
\mathrm{PtRh} \cdot \mathrm{Pt} \text { 熱電対 }\end{array}$ \\
\hline 光高温計 & $800 \sim 1800^{\circ} \mathrm{C}$ & $\begin{array}{l}\text { 光高温計用標準電 } \\
\text { 球 }\end{array}$ \\
\hline $\begin{array}{l}\text { ランドパイロメ } \\
\text { ーター }\end{array}$ & $400 \sim 1300^{\circ} \mathrm{C}$ & $\mathrm{PtRh} \cdot \mathrm{Pt}$ 熱電対 \\
\hline
\end{tabular}


表 2 鉄鋼業における温度計測の 1 次標準の例?

\begin{tabular}{|c|c|c|}
\hline 名 & 適用温度筫囲 & 管 理 精 度 \\
\hline $\begin{array}{l}\text { 基淮ガラス製温 } \\
\text { 度計 }\end{array}$ & $\begin{array}{r}-56 \sim+350^{\circ} \mathrm{C} \\
(8 \text { 本組 })\end{array}$ & $\pm 0 \cdot 1^{\circ} \mathrm{C}$ \\
\hline Pt 測温抵抗体 & $-200 \sim+630^{\circ} \mathrm{C}$ & $\begin{array}{c}100^{\circ} \mathrm{C} \text { 末满 } \\
\pm 0 \cdot 1^{\circ} \mathrm{C} \\
100^{\circ} \mathrm{C} \text { 以上: } \\
\pm 0.1 \%\end{array}$ \\
\hline PtRh.Pt 熱電対 & $600 \sim 1700^{\circ} \mathrm{C}$ & $\pm 0 \cdot 1 \%$ \\
\hline $\begin{array}{l}\text { 光高温計標潐電 } \\
\end{array}$ & $800 \sim 1800^{\circ} \mathrm{C}$ & $\pm 5^{\circ} \mathrm{C}$ \\
\hline 純 Pd 線 & $1552^{\circ} \mathrm{C}$ & - \\
\hline
\end{tabular}

に列挙した標準器のうちで標準電球だけは, 直接に温度 を測るための道具でなくやや異質であるが，これについ ても JIS Z8706(光高温計による温度測定方法)の中の解 説をはじめ近年の研究報告8)などの文献があり，他の標 準温度計と同様にひろく知られているものと言えよう.

つぎに，これらの 2 次標準をチェックするための標準 器すなわち 1 次標準を, 上記の文献7)から紹介する（表 2 ). 表 1 と表 2 とのつながりは, 表 1 の右端の欄に示 されている. 表 2 については, その右端の欄に示されて いる管理精度に注意する必要がある. 現場の最前線で働 く常用温度計をどの程度の精度で管理すべきかは, プラ ントごとにまた対象ごとに異なるので，簡単な表に整理 して示すことは困難のようであるが, 表 2 すなわちプラ ント内 1 次標準の段階でなら, 管理すべき精度はおのず から評価できるもののようである・ただしここで“評価” と称することがらの内容は, 実はかなり複雑なものであ ると言わなければならない.ひと口に言えば，ここでは 現場からの “需要”之基礎標準研究所の “供給” の能力 とが交錯しているのであり，そこに生ずるある意味の矛 盾がひとまず止揚されて，ひとつの釣り合いを形うくつ ているとも言えよう.

\section{3. 基礎標準へのトレーサビリティ}

常用温度計 $\leftarrow$ (比較 $) \rightarrow 2$ 次標準器 $\leftarrow$ (比較 $) \rightarrow 1$ 次標準 器という系統の具体的な例をわれわれは表 1 と表 2 で知 つたわけであるが，さらに進んで，より基礎的な温度計 測標準がどうなつているかを考えようとする場合，話が ここで 2 つ道に分かれることに注意しなければならな い. 一方のルートは, 表 2 の上の 4 つの標準器からさら にいつそう基礎的な標準“器”に結ばれてゆくものであ るが，他方のルートは，表 2 の最下のものすなわち “温 度定点” ( $\mathrm{Pd}$ 融解点はその一例) に結ばれてゆくもので ある.

第1のルートについては, 話はここで一般に企業を離 れて公共機関にもちこまれることになる，すなわち企業 の 1 次標準器は国立・公立その他の機関に搬入され校正 される.この種の公的な校正作業はこれまで主として計
量研究所（通商産業省の工業技術院の試験研究所のひと つ）で行なわれてきており，その行政上の根拠は“計量 法”という法律で定められた “基準器検査”, “比較検査” および工業技術院で制度化されている“低頼試験”など であつた，一方地方の公設機関とくに東京都の工業技術 センターもか标てから電気式温度計の校正業務に少なか らぬ熱意を示してきていたが，近年この種の業務に対す る社会の needs はいちじるしく高まり, 公共機関の作業 の拡充・能率化がつよく要請されるに至つた. 幸いにし て今年（1971年） 4 月から特殊法人 - 日本電気計器検定 所本社標準部においても電気式温度計の依頪試験の業務 が始められて着々と成果があがつていることは, 特記に 值することと言えよう.なお, 計量研究所にせよ電気計 器検定所にせよ，それぞれの地方支所・地方試験所もこ れらの仕事の一部を分担しているので，詳細は各所にお 問い合わせ願いたい.

さて, 表 3 に日本電気計器検定所における電気式温度 計の依赖試験の内容の要点を示す. この業務内容は, か ねてから計量研究所で行なつてきた依頼試験業務の内容 をほぼそのままにコピーしたものになつているので, ひ と口に言えば表 3 は現今ルーチン化されている公共機関 の校正業務の要約と考えてよい.このほか光高温計用標 準電球については計量研究所で1000〜 $1800^{\circ} \mathrm{C}$ の範囲の 耀度温度（波長 $0.65 \mu \mathrm{m}$ ) に関する校正業務を行なつて いる（試験精度 $\pm 5^{\circ} \mathrm{C}$ ）が，この仕事も来年度から日本 電気計器検定所入拡大されてゆく予定である.

ここで表 2 の右端, すなわち企業側で管理上“要求” される精度と, 表 3 の右端, すなわち公共機関側で “供 給”される精度との, 照応の実態を検討しておく必要が あろう. 2 つ表で精度の表現式が異なるが，Pt測温抵 抗体のばあいー $50^{\circ} \mathrm{C} \sim+600^{\circ} \mathrm{C}$ の範囲では “需要” 精 度よりも“供給”精度のほうがよいわけであるから, 不 都合は生じない.ただし上記以外の温度範囲とくにー50 ${ }^{\circ} \mathrm{C}$ 以下については問題が残されている（計量研究所で は扱いうるのであるが完 全にルーチン化されてはいな い). $\mathrm{Pt} \cdot \mathrm{Rh}$ 系の熱電対の場合, 表 3 の $\pm 0.01 \mathrm{mV}$ と いうのは, 熱電特性から略算して $500^{\circ} \mathrm{C} て ゙ \pm 0.2 \%$, $1000^{\circ} \mathrm{C}$ で $\pm 0 \cdot 1 \%$ に相当するから，この“供給”精度 は, 表 2 の “需要” 精度と比べてかろうじて compara-

表 3 日本電気計器検定所における電気式温度計の 依頼試験（昭和 46 年 4 月開始）

\begin{tabular}{|c|c|c|c|}
\hline \multicolumn{2}{|c|}{ 試匰品の種類 } & 試 験 点 & 最高試験精度 \\
\hline \multirow{2}{*}{$\begin{array}{l}P_{\text {t測温 }} \\
\text { 抵抗体 }\end{array}$} & 4 導線式 & \multirow{2}{*}{$-50^{\circ} \mathrm{C} \sim 600^{\circ} \mathrm{C}$} & \pm 0.03 度 \\
\hline & 上記以外 & & \pm 0.05 度 \\
\hline \multicolumn{2}{|c|}{ PR 熱電対 } & $0^{\circ} \mathrm{C} \sim 1100^{\circ} \mathrm{C}$ & $\pm 0.01 \mathrm{mV}$ \\
\hline \multicolumn{2}{|c|}{$\begin{array}{c}\text { CA, IC, CC } \\
\text { 熱 電 対 }\end{array}$} & $0^{\circ} \mathrm{C} \sim 1000^{\circ} \mathrm{C}$ & $\pm 0.05 \mathrm{mV}$ \\
\hline
\end{tabular}


ble というところであるが，温度範囲のほうで比べると $1100^{\circ} \mathrm{C}$ 以上 $1700^{\circ} \mathrm{C}$ までの部分に重大な供給欠除が認 められる. (この点も計量研究所で鋭意, 研究が進めら れているが，ルーチン化にはやはり多少の時間が必要て ある). 光高温計用標準電球の場合需要も供給も $\pm 5^{\circ} \mathrm{C}$ なので，一応マッチしているが，需要は実はもう一段と きびしくなつていることを察せられる.

以上の略述からすでに明らかであろうが，この問題に ついて今日すでにいくつかの供給欠除が指摘されるので あつて，公共機関とくに計量研究所はその解决に大きな 努力を払つているのであるが，その状況は別稿8) その他 の同所の報告によつてご承知いただきたい.

ところで，表 2 についてすでに注意をうながした“温 度定点”の問題, あるいは具体的に言えば “温度定点に よる温度標準とそのトレーサビリティ”の問題が，つぎ に考察されなければならない。

\section{4. 温度定点の役割}

そもそも計測の標準というもののしくみを諭ずる場合 に, 信頼できる計測器を基本と考えるか, あるいは一定 不变な物理的状態を基本と考えるかという大問題がつね につきまとう（学術的な論述ではないが拙著9）を参照し ていただけば幸いである)，本稿で今まで見てきたのは 主として “標準(の計測) 器” のつながりのことであつ た. しかし “温度が一定不変な状態”すなわち “温度定 点”というものは古くから注目され，18世紀にセルシウ ス, フォレンハイ, レオーミュールらが温度計の改良と それらの標準化のために氷点や水の沸騰点を利用したこ とはよく知られているところであろう.

温度定点については, 基礎的な研究 ${ }^{10) た ゙ け て ゙ な く, ~ き ~}$ わめて実用的な応用も考えられるようになつた（たとえ ば純金属および合金 20 余種のピースを原子炉内に置き それらの溶融の有無を観察して $100 \sim 1600^{\circ} \mathrm{C}$ の範囲の 温度を精度 $20^{\circ} \mathrm{C}$ で調べることができる $\left.{ }^{11)}\right)$. 表 2 に記 載されていた Pd 線は温度定点として利用するためのも のであつて，“純金属線溶融による熱電対校正法” はこ の $\mathrm{Pd}$ をはじめ $\mathrm{Au}, \mathrm{Pt}, \mathrm{Cu}, \mathrm{Al}, \mathrm{Zn}, \mathrm{Pb}$ にまで適 用できることになつた．この技法の実用化については日 本学術振興会の分科会および計測自動制御学会の温度計 測研究専門委員会の奇与するところが顕著であつた ${ }^{2) 12)}$. なお筆者らは純金属小片の融解に着目して放射温度計を 校正することを試みている(13)。 また，金属ではなく各種 の有機物質の三重点, 融固点を利用して常温付近の温度 計測標準を充実させることも可能になり ${ }^{14) ， し か も そ れ ~}$ が熱電対の補償導線の特性試験への応用という形で鉄鋼 業での温度計測に導入されつつあるのは, われわれの喜 びとするところである.

ところで, 当然のことながら温度定点による温度計測 標準は融解点その他の特定なひとつの温度での基準を与.
えるにすぎない、いわば蜼散的な標準の役しかない、し かし，いくつかの温度定点を組み合わせて合理的に利用 すると，連続的な標準の代役ともいうべき働きをさせる ことができる．白金・ロジウム系の熱電刘についてはそ のような可能性はすでに各方面で議論されている15).

\section{5. 国際実用温度目盛の意義と構成}

ここで図1に立ちもどると，その中央よりやや左寄り にいくつかの温度定点のスケッチが認められるであろ う. 図1の右端から中央あたりまでには，実用温度計 $($ 比較 $) \rightarrow($ 何段階かの) 橴準温度計という系統, すなわち われわれが 3. で考察した系統が図示されているわけで あるが，その左方に温度定点が図示されているというこ との意義をここで吟味しておかなければならない.

多少の考察によつて理解されるはずのことであるが， 上記のセ(比較) $\rightarrow$ で結ばれた系統には本来なら終点は存 在しない，既述の公共機関が依赖に応じて試験を行なう 際の標潐温度計は，いつたい何との“比較”によつてそ の正確さを保証されているのであろうか. 他の量たとえ ば質量の標準の場合には，国際キログラム原器という世 界唯一の特定物体 (パリ郊外の国際度量衡局の地下原器 庫に敞重に保管されている）が究極の標準の役をするの であつて，わが国の日本キログラム原器（計量研究所に 保管）は国際キログラム原器と綿密に比較されてそれ自 身の正確さが明らかにされている. そしてわが国の質量 測定はすべてこの原器に結びつけられている（原器への トレーサビリティが確立されている).

質量標準のトレーサビリティは上述のとおりにきわめ て即物的でわかりやすいが，温度の計測標準の場合原器 に対応する唯一の物体としての究極の標準器は存在しな い(それを考案し実現することは決して不可能ではある まいが，俗にいつてそれはまつたく“使いものにならな い”し，しいてそれを使いこなそうとしてもいたずらに 混乱を招くだけであろう一一その点は後に再考する).

今われわれは，4．の冒頭に述べた大問題に再び直面 しているのである. つまり温度計測の究極の標準とし て，世界唯一の特定の標準温度計を考えるべきか，ある いは温度が一定不変の状態, すなわち温度定点を考える ベきかという段階まで考察を深めてきたわけである，そ して前者は“使いものにならない”と上に述べたのであ るが，その理由は次のような説明から明らかになろう， 現今もつとも信頼できる標準温度計は $\mathrm{Pt}$ 測温抵抗体お よび所要の周辺機器によつて構成されると思われる. そ れらを現代最高の技術のもとに整備し, 細心の注意のも とに保守しつつ使用すれば $0 \sim 600^{\circ} \mathrm{C}$ 程度の温度範囲で $\pm 0.001^{\circ} \mathrm{C}$ よりよい精度が確保されるであるう（ついで ながらこの精度を表 2 の右端の值と対比してみていただ きたい). この精度は一般の産業計測からの需要”に対 しては十分満足すべきものと判断されるけれども，では 
$0^{\circ} \mathrm{C}$ 以下はどうか, $600^{\circ} \mathrm{C}$ 以上はどうかとなると，数多 (の研究名はなされているものの, $-250^{\circ} \mathrm{C}$ 程度まで, あるいは+ $1100^{\circ} \mathrm{C}$ 程度までの筙团を越えるものではな いし，常温をへだたるほどに精度の低下は覚悟しなけれ ばならない，さらに温度䈤囲をひろげて考えようとする と，本質的な限界に行きあたることになる. なぜなら $\mathrm{Pt}$ は $1800^{\circ} \mathrm{C}$ では完全に融解してしまうので測温抵抗体の 素線としての役をはたしえなくなるからである. Pt 測 温抵抗体が究極の温度標準器として“厅能”でないこと は，明白であろう。

かりに話を常温付近に限るとしても，この標淮器がつ 㸚に $\pm 0 \cdot 001^{\circ} \mathrm{C}$ の精度で正確さを保ちつづけていること は，どのようにして証明されるのであろうか。キログラ 么原器については多年の研究（各国に配られている原器 との系統的な相互比較）の結果，10-8の精度が確証され ている9が，常部的に言えばこれは 1 倜の物体の質量が 保存されるかどうかの問題なのであるから，磨粍その他 のことを撆戒しておけば心配はないと考えられよう．そ れに対して標準温度計のほうは, ある筑囲内にもせよ， さまざまな温度にさらされる宿们にあつて，しかも温度 と電気抵抗との関数関保の保存 (不変性) が要求される のであるから，近時の信頪性工学における議諭などから しても，質量の原器よりはるかに䔅酷な動作条件を課せ られていると考えなければならない，参考までに電気抵 抗測定の標準器（標準抵抗器）の安定性のデータ16)を参 照すると, 温度 $20^{\circ} \mathrm{C}$ の精密恒温そう内に常時きわめて 注意ぶかく保管されている場合に $\pm 10^{-6}$ の程度と評洒 されている. 抵抗標準のこの精度を $\mathrm{Pt}$ 測温抵抗体にあ てはめれば $\pm 0.0002^{\circ} \mathrm{C}$ 程度となる．抵抗の基本標準と さして違わない精度で Pt 測温抵抗体の精度を管理しな ければならないというのはもともと無理な注交なのであ つて, 結局 Pt 測温抵抗体を温度計測の究極の基準とす る考えそのものに陌があると言わざるをえない，いつ そう現実的に考えて，究極の基準として製作・保管して ある $\mathrm{Pt}$ 測温抵抗体の特性が， あるとき突然に，予想の まつたく困難な性質の変化を呈したと仮定してみよう. それが約束として究極の基準の扱いをされているのであ るからには，上記の変化に対応して“すべての”基準温 度計と“すべての” 実用温度計の目盛なり特性表なりは 改められなければならないわけである。そこにひき起こ される混乱は，はかり知れないであろう。

標準温度計の考えだけで究極の温度計測標準を構成す ることの非現実性は，こうして十分に論証されたと言え よう.ところで一方, 温度定点はすでに指摘したと㧍り 離散的な標準の役しかしない，特定唯一の標準温度計に 依存せず，しかも㖞散的でない究極の温度標潐は，一体 ぞのように構成されるべきなのであろうか．18世紀以来 のこの設問は，1854年ケルビンが提唱した熱力学温度目 盛の考えと，1927年以後メートル条約のもとにオーソラ
イズされてきている国際実用温度目盛とによつて, 解決 された.

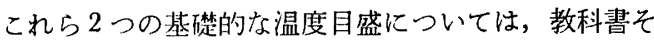
の他にも詳述されているので，それらの構成の理念は周 知のことと思われるが，国際的な協約（とりきめ）とし ての内容にはさまざまな変遷があつた．変遷に応じての 報道にもわれわれは努力してきたつもりであるが，ここ では古い交献の列挙は省略し，現行すなわちメートル条 約にもとづく国際的な最高機関である国際度量総会の最 新の決議に沿ら記述を，付録と表 3 亿示しておく.

表 4 は 1968 年国際実用温度目盛 (IPTS-68) の構成

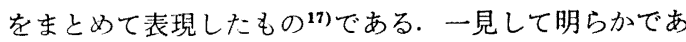
ろうが，その構成はまことに複雑緻密であつて，今それ を解説する余裕はない，国際協約テキストの完訳資料18) その他文献 ${ }^{199}$ 22)を参照していただきたい（また，あえ て言えばこの種の問題のディテイルは計量研究所におま かせ願つてよいと考える).

ただし，IPTS というもののしくみについては一言し ておく、表 4 に見られると打り，IPTS では“標準温度 計”たとえば Pt 抵抗温度計と“温度定点”たとえば水 の沸点, 亜鉛の㠜固点とが併用されているのであつて, 前に考察した 1) 標準温度計のみをたよりにする考えの 欠陥（不変性の保証の欠除）も，また2）温度定点のみ をたよりにする考えの欠宿（離散的な性格）も，ともに たくみに回避されている. 一例をあげれば表 4 の随所に 見られる関数 $W$ とは，Pt 抵抗温度計（ただし，特定の 条件をみたすものであればよいのであつて, 特定唯一の ものを意味するのではない)の $0^{\circ} \mathrm{C}(1$ つの温度定点)に おける抵抗 $R\left(0^{\circ} \mathrm{C}\right)$ に対する，任意の（定義しょうと する）温度における抵抗 $R$ との “比”であつて，比 $W$ と 温度との関係をべースにすることによつて，抵抗 $R$ と温 度との関係をべースにすることの難点を回避しているわ けである. また表4の中のいくつかの数式は，温度定点 方式の㜠散的性格を補うための “補間” 公式と解してお けばよい。

\section{6. 熱力学温度へのより一屏のアプローチ}

究極の温度標準という言葉をすでに何回も用いたが， 上述の IPTS むなお “究極” と呼ぶにはふさわしくな い. なぜなら $\mathrm{Pt}$ 測温抵抗体の抵抗比 $W$ というょうなも のは， Pt という特定物質の性質にかかわり合うのであ るから，ケルビンの唱えた“個々の物質の性質とまつた く無関係な”普遍的温度標準とは意味を異にする．真 に普遍的な，したがつて真に究極的と見なしうる温度標 準は，いうまでもなく熱力学温度目盛（付録）であり， IPTS もまた，その奥に熱力学温度目盛というものが考 えられているからこそ，“究極の一歩手前の実際的標準” の役をにないえているのである.

さて,われわれは図1の右端から考察を始めて, 今よう 
表 41968 年国際実用温度目盛の骨組み禈

新しい国際実用温度目盛 IPTS-68 の定義

\begin{tabular}{|c|c|c|c|}
\hline 温 度 䇥 囲 & \multicolumn{2}{|c|}{ 指定された装置, 方法 } & $T_{68}, t_{68}, T_{68}-273 \cdot 15$ を求める式 \\
\hline $\begin{array}{c}1064 \cdot 43^{\circ} \mathrm{C} \\
\text { 以 上 }\end{array}$ & \multicolumn{2}{|c|}{$\begin{array}{l}\text { 黑体放射 } \\
L: \text { : 黑体のエネルギ一恽度の波 } \\
\quad \text { 長 } \lambda \text { での分光密度 }\end{array}$} & $\begin{array}{l}\frac{L\left(T_{68}\right)}{L\left(T_{68}(\mathrm{Au})\right)}=\frac{\exp \left[c_{2} /\left(\lambda T_{68}(\mathrm{Au})\right)\right]-1}{\exp \left[c_{2} /\left(\lambda T_{68}\right)\right]-1} . \\
\quad c_{2}=0.014388 \text { メートル・ケルビン }\end{array}$ \\
\hline $\begin{array}{l}1064 \cdot 43^{\circ} \mathrm{C} \\
? \\
630 \cdot 74^{\circ} \mathrm{C}\end{array}$ & \multicolumn{2}{|c|}{$\begin{array}{l}\text { 帛金一 } 10 \% \text { ロ ジウム/白金熱電対 } \\
\text { 华 } \\
E_{\mathrm{Au}}=10300 \mu \mathrm{V} \pm 50 \mu \mathrm{V} \\
E_{\mathrm{Au}}-E_{\mathrm{Ag}}=1183 \mu \mathrm{V} \\
\quad+0 \cdot 158\left(E_{\mathrm{Au}}-10300 \mu \mathrm{V}\right) \pm 4 \mu \mathrm{V} \\
E_{\mathrm{Au}}-E\left(630 \cdot 74^{\circ} \mathrm{C}\right)=4766 \mu \mathrm{V} \\
\quad+0 \cdot 631\left(E_{\mathrm{Au}}-10300 \mu \mathrm{V}\right) \pm 8 \mu \mathrm{V}\end{array}$} & 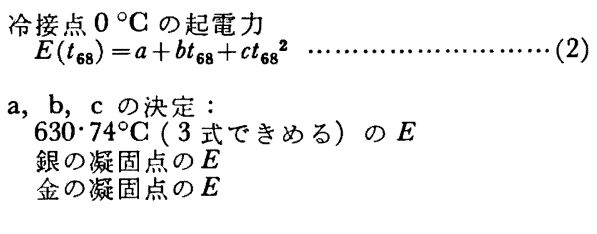 \\
\hline $\begin{array}{c}630 \cdot 74^{\circ} \mathrm{C} \\
? 0^{\circ} \mathrm{C}\end{array}$ & \multicolumn{2}{|c|}{$\begin{array}{l}\text { 白金抵抗温度計 } \\
\text { 条件: } \\
\quad W\left(100^{\circ} \mathrm{C}\right)>1 \cdot 39250 \\
\text { ただ } \\
W\left(T_{68}\right)=R\left(T_{68}\right) / R\left(0^{\circ} \mathrm{C}\right)\end{array}$} & $\begin{aligned} & t_{68}= t^{\prime} \\
&+0 \cdot 045\left(\frac{t^{\prime}}{100^{\circ} \mathrm{C}}\right)\left(\frac{t^{\prime}}{100^{\circ} \mathrm{C}}-1\right)\left(\frac{t^{\prime}}{419 \cdot 58^{\circ} \mathrm{C}}-1\right) \\
&\left(\frac{t^{\prime}}{630 \cdot 74^{\circ} \mathrm{C}}-1\right){ }^{\circ} \mathrm{C} \ldots \ldots \ldots \ldots \ldots \ldots \ldots \ldots(3) \\
& t^{\prime}= \frac{1}{\alpha}\left[W\left(t^{\prime}\right)-1\right]+\delta\left(\frac{t^{\prime}}{100^{\circ} \mathrm{C}}\right)\left(\frac{t^{\prime}}{100^{\circ} \mathrm{C}}-1\right) \cdots(4) \\
& \alpha, \delta \text { の決定 : } \\
& \text { 水の沸点の } W\left(t^{\prime}\right)(\text { あるいは, すずの凝固点の } \\
&\left.W\left(t^{\prime}\right)\right) \text { 要鉛の凝固点の } W\left(t^{\prime}\right)\end{aligned}$ \\
\hline $\begin{array}{c}273 \cdot 15 \mathrm{~K} \\
? \\
90 \cdot 188 \mathrm{~K}\end{array}$ & \multicolumn{2}{|c|}{ 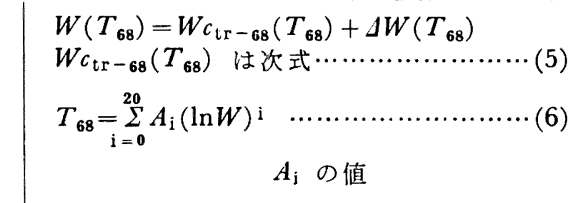 } & $\begin{array}{c}\Delta W=A_{4} t_{68}+B_{4} t_{68}{ }^{3}\left(t_{68}-100^{\circ} \mathrm{C}\right. \\
t_{68}=T_{68}-273 \cdot 15 \cdots \cdots \cdots \cdots \cdots \cdots \cdots(7) \\
\mathrm{A}_{4}, \mathrm{~B}_{4} \text { の決定 : } \\
\text { 水の沸点の } \Delta W\left(\begin{array}{cc}\text { ただし } & W c_{\mathrm{tr}-68} \\
\text { 酸素沸点の } \Delta W\left(\begin{array}{cc} \\
\left.100^{\circ} \mathrm{C}\right)=1 \cdot 39259668 \\
\end{array}\right. & \text { とする }\end{array}\right)\end{array}$ \\
\hline \multirow[b]{2}{*}{$\begin{array}{c}90 \cdot 188 \mathrm{~K} \\
? \\
54 \cdot 361 \mathrm{~K}\end{array}$} & \multirow{4}{*}{$\begin{array}{r}0 \\
1 \\
2 \\
3 \\
4 \\
5 \\
6 \\
7 \\
8 \\
9 \\
10 \\
11 \\
12 \\
13 \\
14 \\
15 \\
16 \\
17 \\
18 \\
19 \\
20\end{array}$} & $A_{\mathrm{i}}$ & \multirow{2}{*}{ 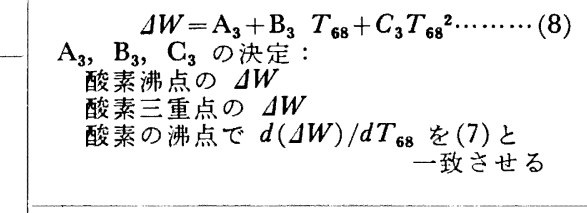 } \\
\hline & & \multirow{3}{*}{$\begin{array}{l}0 \cdot 27315 \times 10^{3} \\
0 \cdot 2508462096788033 \times 10^{3} \\
0 \cdot 1350998699649997 \times 10^{3} \\
0 \cdot 5278567590085172 \times 10^{2} \\
0 \cdot 2767685488541052 \times 10^{2} \\
0 \cdot 3910532053766837 \times 10^{2} \\
0 \cdot 6556132305780693 \times 10^{2} \\
0 \cdot 8080358685598667 \times 10^{2} \\
0 \cdot 7052421182340520 \times 10^{2} \\
0 \cdot 4478475896389657 \times 10^{2} \\
0 \cdot 2125256535560578 \times 10^{2} \\
0 \cdot 7679763581708458 \times 10 \\
0 \cdot 2136894593828500 \times 10^{2} \\
0 \cdot 4598433489280693 \\
0 \cdot 7636146292316480 \times 10^{-1} \\
0 \cdot 9693286203731213 \times 10^{-2} \\
0 \cdot 9230691540070075 \times 10^{-3} \\
0 \cdot 6381165909526538 \times 10^{-4} \\
0 \cdot 3022932378746192 \times 10^{-5} \\
0 \cdot 877551.3913037602 \times 10^{-7} \\
0 \cdot 1177026131254774 \times 10^{-8}\end{array}$} & \\
\hline $\begin{array}{c}54 \cdot 361 \mathrm{~K} \\
? \\
20 \cdot 28 \mathrm{~K}\end{array}$ & & & $\begin{array}{l}\Delta W=\mathrm{A}_{2}+\mathrm{B}_{2} T_{68}+\mathrm{C}_{2} T_{68}{ }^{2}+\mathrm{D}_{2} T_{68}{ }^{3} \cdots(9) \\
\mathrm{A}_{2}, \mathrm{~B}_{2}, \mathrm{C}_{2}, \mathrm{D}_{2} \text { の決定: } \\
\text { 酸素三重点の } \Delta W \\
\text { ネオン沸点の } \Delta W \\
\text { 平衡水素沸点の } \Delta W \\
\text { 酸素三重点で } d(\Delta W) / d T_{68} \text { を(8)と } \\
\end{array}$ \\
\hline $\begin{array}{c}20 \cdot 28 \mathrm{~K} \\
? \\
13 \cdot 81 \mathrm{~K}\end{array}$ & & & $\begin{array}{l}J W=\mathrm{A}_{1}+\mathrm{B}_{1} T_{68}+\mathrm{C}_{1} T_{68}{ }^{2}+\mathrm{D}_{1} T_{68}{ }^{3} \cdots(10) \\
\mathrm{A}_{1}, \mathrm{~B}_{1}, \mathrm{C}_{1}, \mathrm{D}_{1} \text { の決定 : } \\
\text { 平衡水素沸点の } \Delta W W \\
17 \cdot 042 \mathrm{~K} \text { 类 } \Delta W \\
\text { 平衡水素三重点の } \Delta W \\
\text { 平衡水素沸点で } d(\Delta W) / d T_{68} \text { を(9) と } \\
\text { 一致させる }\end{array}$ \\
\hline
\end{tabular}

やく図 1 の左端に到達した. いわゆるトレーサビリティ の最後のくさりは，IPTS $\leftarrow$ (比較) $\rightarrow$ 熱力学温度という 結び目にあたるわけであるが，この結び目における精度
の“需要”と“供給”の関係はどうなのであろうか．結 諭をさつそく書けば，1) IPTS は, 詳細緻密な協約 (表 4 ) のゆえに，ばらつき (偶然誤差) のきわめて少ない 
(“精密さ”のよい) 標準の役をするが，真の究極である 熱力学温度への合致の良否という意味のかたより（系統 誤差) はかならずしも少なくはない（“正確さ”はかな らずしもよくない)，他方 2) 熱力学温度目盛は字義 ど おりの究極の標準とされるものであるがゆえに，それ自 身が（協約として）絶対に正確であり，かたよりはなく 正確さは理想的によいのであるが，なにぶんにも抽象的 理諭に立つものであつて，それを実験的に realize する 際の困難はきわめて大きく，ひいてはばらつき（偶然誤 差）が多く精密さがわるいということになる.この $2 つ$ の温度目盛の間の精度の需要・供給の関係は, 独特な様 相を呈しているのである.

熱力学温度目盛についても研究はこつこつと続けられ ている ${ }^{23}$. その成果として, 上記 2 つの温度目盛の差 (食い違い)があらわにされることもまれではない，その ときに処置は, 論理的には “IPTS の構成を修正して, より正確に熱力学温度目盛に合致させる”ことをおいて ほかにないはずである．そのような処置の集積とともに “すべての温度計測が究極の標準によりよくトレースさ れる”ようになるのである.

\section{7. 温度標準の切り変えのポリシー}

IPTS が年代つきで-48 とか，-60 とか呼ばれてきた のも，前節末尾に述べた処置の年代区分を明らかにする ためになされたことであつた．そして今や-68 という年 代の付せられた最新の協約八の移行処置がとられつつあ るわけで，その経繰や方策は他の機会にも述べた 2017)19) が，移行に伴う温度值変更量は表 5 および図 2 に示すと おりである．この変更量を，実用上の需要精度たとえば
表 2 と比較するとき, 今回の移行処置が意外に深刻な問 題を宿していることが理解されるであろう.もつともわ かりやすい例は Pd 融解点において見られる，これまで

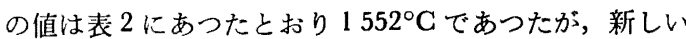
值は $1554 \cdot 3^{\circ} \mathrm{C}$ となる。

わが国の場合公けの移行は計量法の改正の後になされ るのであるが，それは 1971 年末の頃となろう. 他の国 も逐次に移行を進めており，たとえばドイツは 1970 年 12 月 1 日づけで移行を宣言している ${ }^{24}$. 科学技術の見 地からのみでなく輸出入の問題などから見ても，日本に
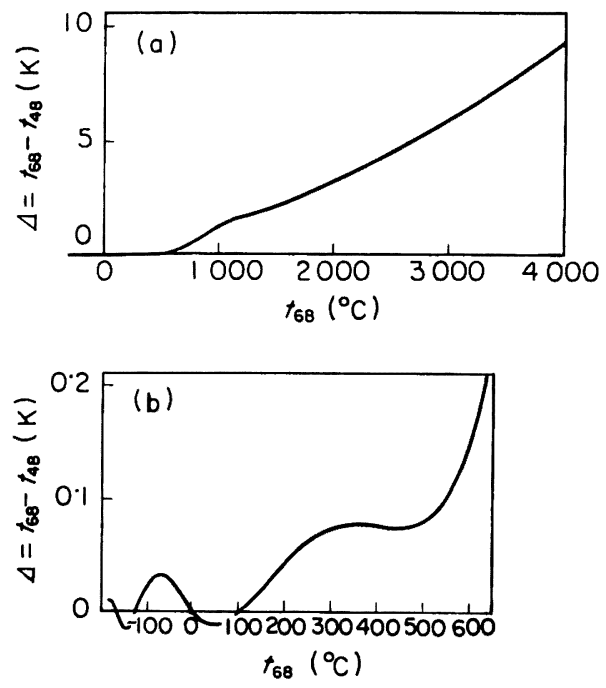

図 2 新旧温度値の差

表 5 新旧温度值の差 $\Delta=t_{68}-t_{48}$ (単位はヶルビン)

\begin{tabular}{|c|c|c|c|c|c|c|c|c|c|c|c|}
\hline$t_{68}^{\circ} \mathrm{C}$ & 0 & -10 & -20 & -30 & -40 & -50 & -60 & -70 & -80 & -90 & -100 \\
\hline $\begin{array}{l}-100 \\
-\quad 0\end{array}$ & $\begin{array}{l}0.022 \\
0.000\end{array}$ & $\begin{array}{l}0.013 \\
0.006\end{array}$ & $\begin{array}{l}0.003 \\
0.012\end{array}$ & $\begin{array}{r}-0.006 \\
0.018\end{array}$ & $\begin{array}{r}-0.013 \\
0.024\end{array}$ & $\begin{array}{r}-0.013 \\
0.029\end{array}$ & $\begin{array}{r}-0.005 \\
0.032\end{array}$ & $\begin{array}{l}0.007 \\
0.034\end{array}$ & $\begin{array}{l}0.012 \\
0.033\end{array}$ & 0.029 & 0.022 \\
\hline$t_{68}{ }^{\circ} \mathrm{C}$ & 0 & 10 & 20 & 30 & 40 & 50 & 60 & 70 & 80 & 90 & 100 \\
\hline $\begin{array}{r}0 \\
100 \\
200 \\
300 \\
400 \\
500 \\
600 \\
700 \\
800 \\
900 \\
1000\end{array}$ & $\begin{array}{l}0.000 \\
0 \cdot 000 \\
0 \cdot 043 \\
0 \cdot 073 \\
0 \cdot 076 \\
0 \cdot 079 \\
0 \cdot 150 \\
0 \cdot 38 \\
0 \cdot 65 \\
0 \cdot 94 \\
1 \cdot 24\end{array}$ & $\begin{array}{r}-0.004 \\
0.004 \\
0.047 \\
0.074 \\
0.075 \\
0.082 \\
0.165 \\
0.40 \\
0.68 \\
0.97 \\
1.27\end{array}$ & $\begin{array}{c}-0.007 \\
0.007 \\
0.051 \\
0.075 \\
0.075 \\
0.085 \\
0.182 \\
0.43 \\
0.71 \\
1.00 \\
1.30\end{array}$ & $\begin{array}{c}-0.009 \\
0.012 \\
0.054 \\
0.076 \\
0.075 \\
0.089 \\
0.200 \\
0.46 \\
0.74 \\
1.03 \\
1.33\end{array}$ & $\begin{array}{c}-0.010 \\
0.016 \\
0.058 \\
0.077 \\
0.074 \\
0.094 \\
0.22 \\
0.48 \\
0.77 \\
1.06 \\
1.36\end{array}$ & $\begin{array}{c}-0.010 \\
0.020 \\
0.061 \\
0.077 \\
0.074 \\
0.100 \\
0.25 \\
0.51 \\
0.80 \\
1.09 \\
1.39\end{array}$ & $\begin{array}{c}-0.010 \\
0.025 \\
0.064 \\
0.077 \\
0.074 \\
0.108 \\
0.27 \\
0.54 \\
0.83 \\
1.12 \\
1.42\end{array}$ & $\begin{array}{c}-0.008 \\
0.029 \\
0.067 \\
0.077 \\
0.075 \\
0.116 \\
0.30 \\
0.57 \\
0.86 \\
1.15 \\
1.44\end{array}$ & $\begin{array}{c}-0.006 \\
0.034 \\
0.069 \\
0.077 \\
0.076 \\
0.126 \\
0.32 \\
0.60 \\
0.89 \\
1.18\end{array}$ & $\begin{array}{c}-0.003 \\
0.038 \\
0.071 \\
0.076 \\
0.077 \\
0.137 \\
0.35 \\
0.62 \\
0.92 \\
0.21\end{array}$ & $\begin{array}{l}0.000 \\
0.043 \\
0.073 \\
0.076 \\
0.079 \\
0.150 \\
0.38 \\
0.65 \\
0.94 \\
1.24\end{array}$ \\
\hline$t_{68}{ }^{\circ} \mathrm{C}$ & 0 & 100 & 200 & 300 & 400 & 500 & 600 & 700 & 800 & 900 & 1000 \\
\hline $\begin{array}{l}1000 \\
2000 \\
3000\end{array}$ & $\begin{array}{l}3 \cdot 2 \\
5 \cdot 9\end{array}$ & $\begin{array}{l}1 \cdot 5 \\
3 \cdot 5 \\
6 \cdot 2\end{array}$ & $\begin{array}{l}1 \cdot 7 \\
3 \cdot 7 \\
6 \cdot 5\end{array}$ & $\begin{array}{l}1 \cdot 8 \\
4 \cdot 0 \\
6 \cdot 9\end{array}$ & $\begin{array}{l}2 \cdot 0 \\
4 \cdot 2 \\
7 \cdot 2\end{array}$ & $\begin{array}{l}2 \cdot 2 \\
4 \cdot 5 \\
7 \cdot 5\end{array}$ & $\begin{array}{l}2 \cdot 4 \\
4 \cdot 8 \\
7 \cdot 9\end{array}$ & $\begin{array}{l}2 \cdot 6 \\
5 \cdot 0 \\
8 \cdot 2\end{array}$ & $\begin{array}{l}2 \cdot 8 \\
5 \cdot 3 \\
8 \cdot 6\end{array}$ & $\begin{array}{l}3 \cdot 0 \\
5 \cdot 6 \\
9 \cdot 0\end{array}$ & $\begin{array}{l}3 \cdot 2 \\
5 \cdot 9 \\
9 \cdot 3\end{array}$ \\
\hline
\end{tabular}


おける 移行は時を失することなく，しかも混乱を生ず ることなく実施されなければならない，既述の国公立機 関は着々と移行の準供を整えているが, 現場の計測の最 前線に至るまでのトレーサビリティ全体の再編成のため には, 関係諸方面での綿密な問題処理が必要である（た とえば計器の目盛の書き改めからコンピューター・プロ グラムの組みなおしに至るまで)，幸いに日本鉄鋼協会 ではこの課題の合理的処理のための小委員会（委員長は 下間照男氏）が設けられ精力的な検討が続けられてい る. 官庁側も, 工業技術院・国際標準研究連絡会議を中 心として日本産業技術振興協会・産業計測標準委員会な どと提携しつつ，処置に柾漏の生じないよう，十分に意 を用いている. 各界においても十分な配虑がなされるこ とを期する次第である.

\section{8. 後記}

IPTS の変更そのものについてはすでに他誌で何回か 解説したので, 本稿では鉄鋼業における温度計測標準卜 レーサビリティの理念の普及を主眼として執筆した．そ のためかえつてて漫な論調に終始したかとおそれる次第 であるが，計測標準の意義を考察していただくために， 多少とも資するところがあれば幸いである.

(1971年 9 月 15 日)

\section{付録 熱力学温度の定洋 ${ }^{20}$}

熱源 A と熱源 B との間で動作する可逆サイクルにおい

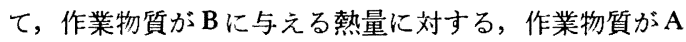
から得る熱量の比を $k_{\mathrm{A}, \mathrm{B}}$ とすれば, 熱力学の第 2 法則 により,一般的関係

$$
k_{\mathrm{A}, \mathrm{B}}=k_{\mathrm{A}, \mathrm{B}}^{-1}
$$

が成立し， $k_{\mathrm{A}, \mathrm{B}}$ したがつて $k_{\mathrm{B}, \mathrm{A}}$ は作業物質の性質とは 無関係であつて，A，Bの温度だけできまる．そこで両 熱源の温度 $T_{\mathrm{A}}$ および $T_{\mathrm{B}}$ の値を

$$
k_{\mathrm{A}, \mathrm{B}}=T_{\mathrm{A}} / T_{\mathrm{B}}
$$

となるように選ぶことができる. この原則にしたがつて 表現された温度が熱力学温度である.

つぎに温度の基準点(基本定点)として水の三重点（添 字 tr）を採用し，その熱力学温度 $T_{\mathrm{tr}}$ を $T_{\mathrm{tr}}=273 \cdot 16 \mathrm{~K}$

と規約すれば，任意の熱源(添字 $\mathrm{x}$ ) の熱力学温度 $T_{\mathrm{x}}$ は $T_{\mathrm{x}}=273 \cdot 16 k_{\mathrm{x}, \mathrm{tr}} \mathrm{K}$
で表わされる.これが現今の熱力学温度の定義であつ て, 国際単位系（S I ） はこれを 6 基本量のひとつに採 用し, 量記号 $T$, 単位名ヶルビン (kelvin), 単位記号 Kを規定している.

またセルシウス温度 (量記号 $t$, 単位記号 ${ }^{\circ} \mathrm{C}$ ) は $t$ $=T-273.15 \mathrm{~K}$ で定義される.

\section{交献}

1) 菅野: 計測と制御, $9(1970) 7$, p. 531

2 ）学振製鋼19委員会：高温測定と溶鋼温度, (1960)，日刊工業新聞社

3 ) 大島, 鈴木: 計測と制御, $9(1970) 11$, p. 837

4) 鈴木：プロセス計測制御便覧, 新版 (1970), p. 137 日刊工業新聞社

5 ) 松田：計測と制御，9(1970)6, p. 460

6 ) $T$. Shimotsuma, et al.: Preprint, 5 th Symposium on Temperature (1971 年6月，ワシントン)

7 ) 島田: 計測自動制御学会, 第15回温度計測部会 (1970年12月 8 日) 資料, 鉄鋼業における温度計測 の精度管理

8 ) 高田: 計量研究所第 4 回学術䛾演会（1971年 6 月 29 日）資料，日本産業技術振興協会で入手可能

9 ) 高田: 単位の進化(ブルーハックス), (1970), 唡 談社

10）高田：日本金属学会会報，8(1969) 1，p. 14

11) P. G. Salgado, et al.: Abstract, 5th Symposium (既出)

12) 下間，ほか：計測と制御，4(1965)12，p. 848

13) 伊藤, 高田: 第10回計測自動制御学会 - 学術䍀演 会 $(1971$ 年 8 月, 德島)

14) 高田, 内山：計測と制御, 4(1965) 12, p. 814 および望月，内山：応用物理， $39(1970) 2$, p. 173

15）花田, 吉武：13）と同様に発表

16) 平山：応用物理, 38(1969)6, p. 591

17）望月：応用物理, 38(1969)6, p. 585

18）計量研究所報告, 18(1969) 3, p. 134

19)同上, p. 114

20) 高田：計測と制御，8(1969)6， p. 378

21) 高田：計測と制御, 9(1970)8, p. 599

22) 三井，小川：計測と制御，9(1970)9， p. 669

23）たとえば $K$. Mitsui, et al.: Preprint, 5th Symposium (既出)

24) PTB-Mitteilungen 1971-1, p. 31

注）文献18）は近く単行本として出版される予定.また1，21）およ び 22）を含む陆義シリーズの合本が計矵自野制御学会で頒布され ている. 